\title{
The Impact of Financing Pressure on the Relationship between Top Managers' Characteristics and Earnings Management
}

\author{
Beibei Yan ${ }^{1 *}$, Hao Yuan ${ }^{2}$
}

${ }^{1}$ Department of Accounting, SILC Business School, Shanghai University, China

${ }^{2}$ SILC Business School, Shanghai University, China

DOI: $10.36348 /$ sjef.2020.v04i06.001

| Received: 24.05.2020 | Accepted: 01.06.2020 | Published: 06.06.2020

*Corresponding author: Beibei Yan

\section{Abstract}

This paper distinguishes top managers' earning management behavior when they are under different financing status, especially focuses on how managers' characteristics will affect companies' earnings management when they have financing demands and pressures. This paper collects data of managers' characteristics from China A-share listed companies and studies it's different influence on earnings management by comparing companies who are newly listed or issue new shares to companies who don't. The results show that financing companies engage more on earning management behavior in general. Gender of top managers has no significant effect on companies' earning management; however, male proportion of top management team will increase earnings management behavior when companies have a demand on financing. Furthermore, the average educational level of top management team has a positive influence on companies earning management and this effect is stronger for companies who have a financing situation. Finally, a younger management team will conduct more earning management behavior in general, but older age managers will positively affect on this behavior when companies have a financing demand.

Keywords: Earnings management, financing demands, managers' characteristics.

Copyright @ 2020: This is an open-access article distributed under the terms of the Creative Commons Attribution license which permits unrestricted use, distribution, and reproduction in any medium for non-commercial use (NonCommercial, or CC-BY-NC) provided the original author and source are credited.

\section{INTRODUCTION}

As a popular research subject in accounting, earnings management has been widely discussed by many scholars from both domestic and abroad. Especially in recent years, researchers have conducted various researches from different angles and perspectives. They seem to reach a common understanding that earnings management refers to a top management behavior of companies to gain profits from discretionary accounting choices and methods that allowed in imperfect accounting standards and government regulations. There are many factors that affect earnings management behavior and companies' financing demand is one of these factors. Companies with financing demands are more eager to attract capital investment and are more willing to appear superior financial status in front of investors. They may engage in more earning management behavior comparing to other companies who have no financing pressure. According to previous studies, earnings management behavior is positively correlated with companies financing demand [1]. Companies with higher financing demand tend to obtain more bank loans through earnings management in order to relieve their financing stress [2]. On the other hand, banks adjust interest rates in response to the level of company's earnings management behavior. Higher level of earnings management will intrigue higher financing cost and more difficult to get a loan granted [3]. Consequently, conducting earnings management by releasing distorted accounting information will deviate companies actual financial position from economic reality, generate distrust between managers and stakeholders, and eventually bring inevitable damages to the benefits of investors, public and companies themselves.

Meanwhile, the characteristics of companies' executives have significant effects on their managerial activities. As the representative of corporation, top managers' salary and remuneration are closely related to companies' financial performance, which gives they a high motivation to conduct earnings management to maximize corporation's and personal benefits [4]. These managerial intentions and activities will be largely influenced by many different internal and external factors. It brings us an interesting research question that how managers' characteristics will affect their earnings management behavior in response to different financing pressures. 
This paper collects data of companies newly listed and companies with new issued shares in China A-share stock market from 2015 to 2017. It also collects data of the characteristics of senior management team from above-mentioned companies, especially focus on age, gender and education level etc., to examine the research question. As a result, we find out that financing companies engage more on earning management behavior in general and gender of top managers has no significant impact on companies' earning management. However, when analyse further, this paper find out that the increased male proportion of top management team will increase earning management behavior when companies have a demand on financing. Furthermore, the average education level of management team has a positive influence on earnings management and companies' financing demand will worse it. Finally, the younger management team will conduct more earning management behavior, but when companies are under financing status, age of top managers will positively affect it.

This paper further expands the relevant research on the influence of the characteristics of top managers on companies' earnings management, and how financial pressure affects managers' business decision and behavior. It provides insights to company stakeholders and government with regard to credit issuance and corporate governance. It can help regulators make better understanding and adjustment regarding earning management related issues. For the top tier of a company, this paper sheds light on how managers' characteristics play a significant role on their managerial activities that could promote better governance and appointment. Finally, this paper is beneficial to investors who want to make more reasonable and appropriate investment decisions based on accounting disclosure and prevent themselves from accounting distortion and fraud.

\section{LITERATURE REVIEW}

Researches on earnings management started from 1980s, and the existence and significance of earnings management are universal. This issue has a wide influence on the world and attracts many scholars, both domestic and international, to conduct comprehensive and in-depth analysis from all kinds of perspectives. Although scholars did not form a unified definition or understanding of earnings management, they have achieved consensus in certain level. First, management team of the company is the major active party and leader of earnings management. Second, the purpose of earnings management is to maximize the benefit for management's interest or for companies' interest. Third, earnings management behavior will decrease the quality of companies' accounting information disclosure to some extent [5-8].
Other scholars try to define earnings management from different perspectives. Deng chunhua [9] studied this topic from game theory and believed that earnings management is a process in which manager's game with various stakeholders for the maximization of their own benefits and the interests of companies. Ping yaning [10] proposed that earnings management is actually due to the information asymmetry between companies and society. As a result, managers have the opportunity to forge unreal transactions and cook their own financial statements through professional knowledge, in order to obtain supreme gains. In 2014, Wu zhengjie [34] found that managers' earning management may be more active under relevant stimulation. In order to pursuit personal benefits and companies interests, top managers have strong motivation for earnings management, especially for those companies who have needs on capital raising and face financing pressures.

First, under the current regulations of Chinese stock market, a company with listing wish needs to meet strict criterion on financial performance. It highly stimulates managers' intention to adjust companies' financial results in order to have a listing opportunity. Liu ye, Fang libin and Jiang yi [11] found evidences those companies adjusted accounting profit in order to meet the requirements during IPO process. Zhou qunhua [12] studied A-share listed IPO companies in China stock market from 2010 to 2011 and found that companies had both real earnings management and accrual earnings management during listing, and their earnings would drop suddenly and seriously after successfully listed.

Second, before the reform of equity division, allotment of shares was very common among many channels of corporate refinancing. The return on equity ratio is regarded as an important criterion to evaluate the qualification of companies' allotment of shares. Therefore, in order to obtain this right, companies have very strong incentives to adjust their earnings through earnings management. After the reform, allotment of shares is gradually replaced by issuing new shares. Issuing new shares has become the major method of equity refinancing to listed companies in China market. $\mathrm{Gu}$ zhenwei [13] found that most listed companies would intervene in corporate accounting activities through earnings management, so as to adjust corporate earnings to avoid losses. Consequently they change the return on equity rate to make them qualified for allotment of shares or issuing new shares. Zhang weidong et al. [14] also found that earnings management behavior of Chinese companies is particularly obvious before allotment of shares and issuing new shares in public. Wang xiaoliang and $\mathrm{Yu}$ jing [15] found that all companies conducted upward earnings management on their financial information in the year before the issuance of additional shares. 
Finally, there often exists a separation of ownership and management in corporate governance. The shareholders of a company usually hire capable people as representatives to manage the corporation and it causes an information asymmetry between the management and the shareholders of the company. Managers are in the superior position of information control, and can directly execute their rights on corporate operation and management. If shareholders are negligent on their duty of corporate supervision, managers have the ability and freedom to engage earnings management to achieve their purpose. Many scholars found out that managers' interest may be temporary and short term orientated due to the lack of equity ownership. Managers may carry out excessive earnings management in order to meet the requirements of shareholders and obtain instant personal benefits, which may lead to a negative influence and potential threats on companies' earnings performance in future years [16-18]. It clearly shows that the most fundamental reason behind earnings management is the agency problem between shareholders and managers. Managers may have a strong motivation to conduct earnings management, such as establish a wanted public image of corporations or meet companies' financing demands, so as to maximize the related benefits.

\section{Therefore, the first hypothesis of this paper is}

H1: Companies will have more earnings management behaviors when they face financing demands.

Furthermore, the characteristics of corporate executives will determine how they handle companies' problems. Many scholars have studied the effect of managers' characteristics on corporate operating activities, such as influences of age, education background, education level, gender and tenure etc. It is suggested that the characteristics of managers' personality are unique and cannot be duplicated. These personalized traits will affect managers' decision making behavior in their positions, reflecting in various managerial styles and professional capabilities among them. The influence of such characteristics on corporate management is uncontrollable and is shown in a subtle way.

In this area, Chinese scholars have discovered a lot of interesting findings in researches on the influence of managers' characteristics on companies' decision-making. Sun et al. [9] found in their research on IT corporations in 2006 that the age of top managers has a positive correlation with companies' short-term performance, while has an opposite effect on long-term performance. Lin yong and Zhou yanqiao [20] studied non-financial corporations listed in China stock market in 2010 and found that the education and profession background of top managers have a significant positive relationship with companies' long-term financial performance. Therefore they suggested that corporations should pay more attention to managers' education and profession background in hiring. Furthermore, Wu et al. [21] found that managers' tenure is positively related to companies' investment efficiency. Lin \& Lin [22] found that the average age of top managers in domestic companies was positively correlated with investment efficiency. Niu [23] found in her doctoral dissertation that the proportion of female managers in companies' top management team is positively related with investment efficiency.

In terms of the relationship of managers' characteristics and earnings management, scholars also did comprehensive research. Krishnan and Parsons [24] showed that improving the gender diversity of corporate managers would benefit corporate performance, and that women are likely to be more ethical in their judgment and behavior than men. They suggested that companies with more women in senior management are found to be more profitable and have higher stock returns than others. Gavious et al. [25] shows evidence that there is a negative relation between the presence of female directors and earnings management. Lakhal et al. [26] conducted an empirical study on French companies and found that the proportion of women on the board standing as a director or a chair reduces earnings management. This finding suggests that women are effective on their monitoring role and are then considered as a crucial corporate governance device. All these evidences suggest that more male managers in the top management team, more earnings management activities companies carried out. Therefore, this paper proposes the second hypothesis:

$\mathrm{H} 2$ : The proportion of male managers in top management team is positively correlated with companies earning management behavior; and this relationship is stronger in companies with financing demands.

Yijie, Chihua and Chen [27] studied the influence of educational and professional background of the top management team on earnings management using 4,690 firm-year observations from Taiwanese listed firms during 2006 to 2010 . Results show that the proportion of managers who have master's degree or above is negatively correlated with the probability of real earnings management and the proportion of managers who possess a CPA has the opposite effect. However, Wang chao [28] also examined the relationship of top managers' characteristics and earnings management using 442 Chinese companies listed in Shenzhen stock market during 2007 to 2011. He found an insignificant negative effect of manager's education level on earnings management. Furthermore, Sun et al. [29] found a significant negative effect from companies in China coal industry. Based on prior conflicted results, we incline to suggest that well educated top managers would have more professional knowledge and capabilities to perform earnings management behavior and here we propose that: 
H3: The average educational degree of managers in top management team is positively correlated with companies' earning management behavior; and this relationship is stronger in companies with financing demands.

Finally, with regard to the age of top managers, many scholars found that younger managers have higher risk preference in business decisions; they are more willing to take risk in order to obtain higher returns. In contrast, older managers who have accumulated years of experience and reputation are inclined to risk-free and tend to make more conservative decisions in corporate business activities [30, 31]. Some scholars have found similar results suggesting that the average age of top management team is negatively related with companies' earnings management and restatement [28, 32]. Therefore, we propose that:

H4: The average age of managers in top management team is negatively correlated with companies' earning management behavior; and this relationship is stronger for companies with financing demands.

\section{METHOD}

In this paper, we use modified Jones model to calculate the absolute value of the discretionary accruals as an estimator of earnings management. We don't distinguish between upward and downward earnings management, sine it will cause damages to stakeholders' benefits regardless of the direction.

$$
\frac{T A_{i, t}}{A_{i, t-1}}=\alpha \frac{1}{A_{i, t-1}}+\beta_{1} \frac{\Delta R E V_{i, t}-\Delta R E C_{i, t}}{A_{i, t-1}}+\beta_{2} \frac{P P E_{i, t}}{A_{i, t-1}}+\varepsilon_{i, t}
$$

In equation 1 , TA represents for the period t's accrued profit of company i. $\triangle \mathrm{REV}$ represents the difference between current and last period's revenue. $\triangle \mathrm{REC}$ represents the difference between current and last period's account receivables. PPE is the period t's ending balance of fixed assets. All items are adjusted by the total assets of last period.

$$
\begin{aligned}
& T A_{i, t}=D A_{i, t}+N D A_{i, t} \\
& \frac{N D A_{i, t}}{A_{i, t-1}}=\alpha \frac{1}{A_{i, t-1}}+\beta_{1} \frac{\Delta R E V_{i, t}-\Delta R E C_{i, t}}{A_{i, t-1}}+\beta_{2} \frac{P P E_{i, t}}{A_{i, t-1}}
\end{aligned}
$$

In equation 3 , the total accrued profit includes discretionary accruals (DA) and non-discretionary accruals (NDA). As a result, the residuals from equation (1) represent the discretionary accruals (DA) and are our estimates of company's earnings management. Furthermore, we use the following four independent variables to test our research hypothesis. First, a dummy variable "Fin" represents a company who has financing demands and is facing financing pressures. The value 1 represents a company who is newly listed or has allotment of shares or issues new shares in the current period. Second, we use a variable "Gend" to represent the gender characteristics of top management team. It is calculated using the number of male managers divided by the total number of top management members. Third, we use the variable "Edu" represents the education level of top management team. It is calculated using the number of managers who possess a master degrees or

$$
T A_{i, t}=O R_{i, t}-C F O_{i, t}
$$

In equation 2, OR is company i's period t's operating earnings and CFO is period t's cash flow from operating activities.

$$
|D A|=\alpha_{0}+\beta_{1} \text { Fin }+\beta_{2} \text { Gend }+\beta_{3} \text { FinXGend }+\beta_{4} \text { Controls }+\varepsilon
$$




\section{RESULTS}

Table-1: Descriptive analysis

\begin{tabular}{|l|c|c|c|c|c|}
\hline Variable & Obs & Mean & Std. Dev. & Min & Max \\
\hline $\mid$ DA $\mid$ & 12,434 & 0.07 & 0.05 & 0.01 & 0.18 \\
\hline Fin & 13,514 & 0.21 & 0.41 & 0 & 1 \\
\hline Gend & 10,957 & 0.83 & 0.16 & 0.5 & 1 \\
\hline Edu & 10,957 & 0.61 & 0.28 & 0.125 & 1 \\
\hline Age & 10,957 & 51 & 4.21 & 44 & 58 \\
\hline Lev & 13,514 & 0.42 & 0.20 & 0.10 & 0.81 \\
\hline Size & 13,514 & 22.16 & 1.19 & 20.18 & 24.52 \\
\hline Indus & 13,514 & 4.41 & 1.21 & 2 & 6 \\
\hline Year & 13,514 & 2017 & 1.17 & 2015 & 2019 \\
\hline
\end{tabular}

In table 1 we can see the descriptive analysis results of whole database. In our sample, $21 \%$ companies are in the middle of financing status. The average percentage of male managers in top management team is around $83 \%$ and the minimum number is $50 \%$. As to the education level, an average number of $61 \%$ of managers possess a master degree or above. The average age of managers in top management team is 51 with a maximum average age 58 and a minimum average age 44 . In addition, the average leverage level in our sample is $42 \%$ with a range of changes from $81 \%$ to $10 \%$.

Table-2: correlation matrix

\begin{tabular}{|c|c|c|c|c|c|c|c|c|c|}
\hline & $|\mathbf{D A}|$ & Fin & Gend & Edu & Age & Lev & Size & Indus & Year \\
\hline$|\mathbf{D A}|$ & 1 & & & & & & & & \\
\hline \multirow{2}{*}{ Fin } & 0.0879 & 1 & & & & & & & \\
\hline & $* * * 0$ & & & & & & & & \\
\hline \multirow[t]{2}{*}{ Gend } & 0.0147 & -0.0104 & 1 & & & & & & \\
\hline & 0.14 & 0.28 & & & & & & & \\
\hline \multirow[t]{2}{*}{ Edu } & 0.0805 & -0.064 & 0.0511 & 1 & & & & & \\
\hline & $* * * 0$ & $* * * 0$ & $* * * 0$ & & & & & & \\
\hline \multirow[t]{2}{*}{ Age } & 0.0017 & -0.0267 & 0.1725 & 0.0369 & 1 & & & & \\
\hline & 0.87 & $* * * 0.01$ & $* * * 0$ & $* * * 0$ & & & & & \\
\hline \multirow[t]{2}{*}{ Lev } & 0.2058 & -0.1255 & 0.05 & 0.1656 & 0.0609 & 1 & & & \\
\hline & $* * * 0$ & $* * * 0$ & $* * * 0$ & $* * * 0$ & $* * * 0$ & & & & \\
\hline \multirow[t]{2}{*}{ Size } & 0.2024 & -0.0406 & 0.1332 & 0.21 & 0.2366 & 0.5066 & 1 & & \\
\hline & $* * * 0$ & $* * * 0$ & $* * * 0$ & $* * * 0$ & $* * * 0$ & $* * * 0$ & & & \\
\hline \multirow[t]{2}{*}{ Indus } & -0.1667 & -0.0179 & 0.0022 & -0.0303 & 0.0598 & -0.0123 & -0.0533 & 1 & \\
\hline & $* * * 0$ & $* * 0.04$ & 0.82 & $* * * 0$ & $* * * 0$ & 0.15 & $* * * 0$ & & \\
\hline \multirow[t]{2}{*}{ Year } & -0.0608 & -0.1686 & 0.0101 & 0.0236 & -0.0847 & -0.0115 & 0.0433 & 0.0057 & 1 \\
\hline & $* * * 0$ & $* * * 0$ & 0.29 & $* * 0.01$ & $* * * 0$ & 0.18 & $* * * 0$ & 0.51 & \\
\hline
\end{tabular}

Notes: $* * *$, and $* * *$ denote statistical significance at the 10 percent, 5 percent, and 1 percent levels, respectively

Table 2 shows the correlation matrix of all variables. As a preliminary test on our research questions, we can see that companies' financing status is positively correlated with earnings management behavior. This is consistent with hypothesis 1 . Managers educational level also has a positive effect on companies earnings management. The percentage of male managers is positively correlated with earnings management. The direction is consistent with our hypothesis but not significant. The average age of top managers shows a positive but insignificant effect on earnings management behavior which is contrary to our expectation. In addition, companies' leverage and size are positively correlated with earnings management. 
Table-3: Regressions

\begin{tabular}{|l|c|c|c|c|c|}
\hline & $\mathbf{1}$ & $\mathbf{2}$ & $\mathbf{3}$ & $\mathbf{4}$ & $\mathbf{5}$ \\
\hline & $|\mathbf{D A}|$ & $|\mathbf{D A}|$ & $|\mathbf{D A}|$ & $|\mathbf{D A}|$ & $|\mathbf{D A}|$ \\
\hline Fin & $0.01^{* * *}$ & & & & $0.01^{* * *}$ \\
\hline Gend & $(8.67)$ & & & & $(8.44)$ \\
\hline & & -0.00 & & & -0.00 \\
\hline Edu & & $(-0.86)$ & & & $(-0.36)$ \\
\hline & & & $0.01^{* * *}$ & & $0.01 * * *$ \\
\hline Age & & & $(3.21)$ & & $(3.63)$ \\
\hline & & & & $-0.00^{* * *}$ & $-0.00^{* *}$ \\
\hline Indus & & & & $(-3.18)$ & $(-2.57)$ \\
\hline & $-0.01 * * *$ & $-0.01^{* * *}$ & $-0.01^{* * *}$ & $-0.01 * * *$ & $-0.01^{* * *}$ \\
\hline Lev & $(-18.42)$ & $(-16.96)$ & $(-16.92)$ & $(-16.66)$ & $(-16.55)$ \\
\hline & $0.04 * * *$ & $0.03 * * *$ & $0.03 * * *$ & $0.03 * * *$ & $0.03 * * *$ \\
\hline Size & $(15.29)$ & $(12.59)$ & $(12.34)$ & $(12.35)$ & $(13.01)$ \\
\hline & $0.00^{* * *}$ & $0.01^{* * *}$ & $0.00^{* * *}$ & $0.01^{* * *}$ & $0.00^{* * *}$ \\
\hline Year & $(11.59)$ & $(11.28)$ & $(10.68)$ & $(11.70)$ & $(9.86)$ \\
\hline & $-0.00^{* * *}$ & $-0.00^{* * *}$ & $-0.00^{* * *}$ & $-0.00^{* * *}$ & $-0.00^{* * *}$ \\
\hline cons & $(-5.21)$ & $(-6.48)$ & $(-6.53)$ & $(-6.78)$ & $(-5.11)$ \\
\hline & $3.66^{* * *}$ & $5.09^{* * *}$ & $5.13^{* * *}$ & $5.36^{* * *}$ & $4.10^{* * *}$ \\
\hline F value & $(5.17)$ & $(6.45)$ & $(6.50)$ & $(6.76)$ & $(5.09)$ \\
\hline Adj R-squared & 246.38 & 183.12 & 185.21 & 185.17 & 126.83 \\
\hline vif & 0.0898 & 0.0817 & 0.0826 & 0.0826 & 0.0896 \\
\hline N & 1.15 & 1.14 & 1.15 & 1.16 & 1.14 \\
\hline & 12434 & 10234 & 10234 & 10234 & 10234 \\
\hline
\end{tabular}

Notes: *,**, and *** denote statistical significance at the 10 percent, 5 percent, and 1 percent levels, respectively

Table 3 shows the individual and combined regression results of explanatory variables on earnings management. Consistent with hypothesis 1, companies' financing status has a significant positive effect on earnings management. Partially consistent with hypothesis 3 , managers' educational level is positively correlated with companies' earnings management and this relationship is significant. Top managers' gender didn't appear to be a significant influence factor on earnings management. This finding is different from some previous literature suggesting that male managers have more motivation to conduct earnings management $[25,26]$. It is also different from what Ge [33] found that female manager percentage has a positive relationship with companies earnings management. It could be a sign indicating that Male and Female characteristics don't distinguish each other regarding to earnings management when companies are in general condition. Finally, the average age of top managers has a significant negative effect on companies earnings management. This is also partially consistent with our hypothesis 4 .
Table-4: Regressions

\begin{tabular}{|l|l|l|l|}
\hline & 6 & 7 & 8 \\
\hline & $|\mathbf{D A}|$ & $|\mathbf{D A}|$ & $|\mathbf{D A}|$ \\
\hline Gend & -0.00 & & \\
\hline & $(-1.30)$ & & \\
\hline FinXgend & $0.01^{* * *}$ & & \\
\hline & $(7.93)$ & & \\
\hline Edu & & $0.00^{* *}$ & \\
\hline & & $(2.24)$ & \\
\hline FinXedu & & $0.01^{* * *}$ & \\
\hline & & $(7.48)$ & \\
\hline Age & & & $-0.00^{* * *}$ \\
\hline & & & $(-2.97)$ \\
\hline FinXage & & & $0.00^{* * *}$ \\
\hline & & & $(8.08)$ \\
\hline Indus & $-0.01^{* * *}$ & $-0.01^{* * *}$ & $-0.01^{* * *}$ \\
\hline & $(-16.87)$ & $(-16.81)$ & $(-16.62)$ \\
\hline Lev & $0.04^{* * *}$ & $0.03^{* * *}$ & $0.03^{* * *}$ \\
\hline & $(13.42)$ & $(13.04)$ & $(13.23)$ \\
\hline & & & \\
\hline
\end{tabular}




\begin{tabular}{|l|l|l|l|}
\hline Size & $0.00 * * *$ & $0.00 * * *$ & $0.00 * * *$ \\
\hline & $(10.26)$ & $(9.73)$ & $(10.57)$ \\
\hline Year & $-0.00 * * *$ & $-0.00 * * *$ & $-0.00 * * *$ \\
\hline & $(-4.95)$ & $(-5.20)$ & $(-5.16)$ \\
\hline cons & $3.94 * * *$ & $4.13 * * *$ & $4.14 * * *$ \\
\hline & $(4.92)$ & $(5.17)$ & $(5.14)$ \\
\hline F value & 164.01 & 164.5 & 166.16 \\
\hline Adj R-squared & 0.0872 & 0.0875 & 0.0883 \\
\hline vif & 1.14 & 1.15 & 1.16 \\
\hline $\mathbf{N}$ & 10234 & 10234 & 10234 \\
\hline
\end{tabular}

Notes: *,**, and $* * *$ denote statistical significance at the 10 percent, 5 percent, and 1 percent levels, respectively

In table 4 , the results show the interactive effect of financing status with other characteristic of managers on earnings management. Financing status is removed from the model due of collinearity. First, the educational level of top managers is still significantly positively correlated with earnings management. And this effect is even stronger when companies have a financing demand. The average age of top managers is negatively related to company's earnings management. However when companies are under financing pressures, average age of top managers will have a positive effect on company's earnings management. And the gender effect also appears differently when it interacts with companies financing status. It suggests gender didn't have a significant effect on earnings management in general, but when companies have financing demands, male percentage of managers in top management team will be more motivated to earnings management.

\section{CONCLUSION}

Earnings management has been widely researched by scholars all over the world, while a large difference may exist on research directions and angles, researchers have a relatively united definition on earnings management which refers that the top management team distort or forge financial information in pursuit of the maximization of their own or corporate interests within the scope of general accepted accounting principles. Meanwhile, companies who have listing intentions and financing demands are subject to strict regulations on financial disclosures. It provokes a strong incentive of companies to conduct earnings management to meet these performance requirements. Therefore, how managers' characteristics will affect companies' earnings management behavior, especially when companies face an urge financing demand, intrigues researchers' attention.

This paper investigates the effect of top managers' characteristics on earnings management, especially when companies are facing financing demands and pressures. By using a data of 13514

observations from China A-share stock market, this paper found a different pattern of managers' earning management behavior in different financing status. The results show that in general financing companies engage more on earning management behavior. Gender has no significant effect on companies' earning management; however, male proportion of top management team will increase earning management behavior when companies have a demand on financing. Furthermore, the average educational level of top management team has a positive influence on companies earning management and this effect is stronger for companies who have a financing situation. Finally, a younger management team will conduct more earning management behavior normally, but older age managers will positively affect on this behavior when companies have a financing demand.

These interesting findings show that top managers could behave very differently when face different financing conditions. Managers' behavior is not always consistent especially when they need to deal with risks or challenges. The effect of managers' characteristic should be treated with care in different business situations.

\section{REFERENCES}

1. Chen, Y.A.N., Jiayin, L.I., \& Mengshun, L.I. (2016). "Earnings Management, External Financing Demand and Insufficient Corporate Investment - An Empirical Study on Chinese Listed Company." Macroeconomic research, 9:106-117.

2. Taiping, L.U., Zhang, D. (2014). "Financing Demand, Financing Constraint and Earnings Management." Accounting Research, 1; 35-41.

3. Jingxia, Y.U.(2001). "Empirical Study on Earnings Management and Cost of Bank Debt Financing - Evidence from China Stock Market." Public Finance Research, 11:68-72.

4. Healy, P.M.(2005). The effects of bonus schemes on accounting decisions.

5. Schipper, K. (1989). Earnings management. Accounting horizons, 3(4), 91.

6. Healy, P. M., \& Wahlen, J. M. (1999). A review of the earnings management literature and its implications for standard setting. Accounting horizons, 13(4), 365-383.

7. Brown, P. R. (1999). Earnings management a subtle (and troublesome) twist to earnings quality. Journal of Financial Statement Analysis, 4, 61-64.

8. Beneish, M. D.(2001). "Earnings Management: A Perspective." Managerial Finance, 27(12):3-17.

9. Deng, C.(2003). "A Study on the Problem of Earnings Management Based on Game Theory." Accounting Research, 5:37-42.

10. Ning, Y.(2005). "Discussion about Earnings Management.” Accounting Research, 06. 
11. Liu, Y.E., Fang, L., \& Jiang, Y.I. (2013). "Interaction and Regulatory Inspiration of IPO Earnings Management Motivation and Underwriter's Choice Decision - Research on Bilateral Matching Model." Shanghai Finance,08; 65-69.

12. Qun-hua, Z. H. O. U. (2015). Audit Quality and IPO Performances_-An empirical study of Ashare IPO company earnings management. Journal of Jinggangshan University (Social Sciences), (6), 9.

13. Zhenwei, G. U. (2008). "Empirical Study on Earnings Management Motivation and Mode of Listed Companies in China." Shanghai Jiaotong University, Dissertation.

14. ZHANG, W. D., LIU, Z. X., \& SUN, Y. F. (2013). A Comparative Study of Earnings Management between Seasoned Public Offering and Directional Seasoned Offering. Contemporary Finance \& Economics, 1 .

15. Wang, X., \& Yu, J.(2016). "Directed Issuance, Earnings Management and Stock Liquidity." Research on Financial and Economic Issues, 1; 6471.

16. Xianhui B, Liansheng W. The Governance Roles of State-owned Controlling and Institutional Investors: A Perspective of Earnings Management [J]. Economic Research Journal. 2009;2:81-91.

17. Jianying, L.I., \& Dai, L. (2014). "Relationship Study of Executive Compensation and Earnings Management: Empirical Evidence from Listed Companies in China." Journal of South China University of Technology (Social Science Edition), 1;11-18.

18. Jiang, L.I.(2017). “Top Managers Incentive, Real Earnings Management and Corporate Value Based on Empirical Data of A-Share Listed Companies." Caixun, 12:36-37.

19. Sun, H. F., Yao, Z. H., \& Yan, M. S. (2006). The effect of demographic traits of TMT on performance of textile and IT corporations. Nankai Bus Rev, 9(6), 61-67.

20. LIN, Y., \& ZHOU, Y. (2011). Education of executives and their corporate performanceBased on empirical data from GEM. Journal of Central South University (Social Science), (5), 9.

21. WU, L., ZHANG, Y., \& ZHANG, T. (2015). Executive Tenure, R\&D Expenditures and Enterprise Investment Efficiency: Empirical Evidence from China A-share Capital Market. Journal of Nanjing Audit University, (5), 7.

22. Lin, C., \& Lin, Y. I. (2014). "Senior Managers Background and Corporate Investment Efficiency - Empirical Evidence from Chinese Listed
Companies." Journal of Xiamen University (Arts and Social Sciences), 2:100-109.

23. Niu, F. (2017). "Research on Executive Background Characteristics, Compensation Incentive and Enterprise Inefficient Investment." Northeast University of Finance and Economics, Doctoral dissertation.

24. Krishnan, G. V., \& Parsons, L. M. (2008). Getting to the bottom line: An exploration of gender and earnings quality. Journal of Business Ethics, 78(12), 65-76.

25. Gavious, I., Segev, E., \& Yosef, R. (2012). Female directors and earnings management in high- technology firms. Pacific Accounting Review.

26. Lakhal, F., Aguir, A., Lakhal, N., \& Malek, A. (2015). Do women on boards and in top management reduce earnings management? Evidence in France. Journal of Applied Business Research (JABR), 31(3), 1107-1118.

27. Li C, Tseng Y, Chen TK. Top management team expertise and corporate real earnings management activities. Advances in accounting. 2016 Sep 1; 34:117-32.

28. Wang, C. (2013). "An Empirical Study on the Relationship between Executive Characteristics and Earnings Management." Communication of Finance and Accounting, 6:31-33.

29. Sun, Y., Che, X., \& Lang, L. (2019). A Study on the Relationship between Executive Characteristics and Earnings Management in China Coal Industry." China Coal, 7; 10-13.

30. Vroom, V. H., \& Pahl, B. (1971). Relationship between age and risk taking among managers. Journal of applied psychology, 55(5), 399.

31. Wiersema, M. F., \& Bantel, K. A. (1992). Top management team demography and corporate strategic change. Academy of Management journal, 35(1), 91-121.

32. He, W. F., \& Liu, Q. L. (2010). A Study on the Relationship between the Characteristics of the Background of the Top Managers of China's Listed Companies and Their Behavior of Financial Restatement. Management World, 7, 144-155.

33. Ge, C. (2016). "An Empirical Study on the Influence of Executive Gender, Age and Enterprise Nature on Earnings Management." Global Market, 29; 29-30.

34. Zhengjie, W.U., Liyun, W.U. (2014). "Opportunism or Conservatism? Empirical Evidence on Earnings Management Behavior of Listed Companies." Journal of Chifeng College: Natural Science Edition, 19; 116-118. 